\title{
E. S. CARMAN
}

\author{
One of the Greatest of American Plant Breeders-His Work Too Little \\ Appreciated-Success With Potatoes Most Noteworthy-His \\ Activity as a Journalist. \\ E. M. EAsT \\ Bussey Institution, Forest Hills, Massachusetts.
}

I $T$ IS a delightful epigram but hardly the actual truth that "If a man preach a better sermon, write a better book, or build a better mouse-trap than his neighbor, though he hide himself in the wilderness, the world will make a beaten path to his door." The world as a whole is likely to give its applause to some very unimportant people. And after all is it not probable that too general a commendation encourages superficial rather than solid work? The anti-socialistic argument that a more even distribution of earthly comforts would oppose progress because it limits ambition is a pure sophism. Few things worth doing have been done with either money, power or fame in view. For this reason there is no need to feel sorry that E. S. Carman, great alike as agricultural journalist, public spirited citizen and creator of new varieties of plants, never received the panegyrics of which some others have been since the recipients. He had the happiness described by Marcus Aurelius: "A man's happiness-to do the things proper to man." Not that Mr. Carman was unknown-perhaps the editor of no rural paper was admired and trusted more-but, even with the temptation of a private medium for exploiting his triumphs, he did no more than describe carefully and impartially success and failures alike with the honesty of a true nature-lover and born investigator.

Mr. Carman would probably have denied that he was a great plant breeder. He originated no new methods and made few contributions to the study of heredity; but he did discover many interesting facts during his hybridization experiments and he added hundreds of millions of dollars to the wealth of the country, keeping nothing for himself. He was a national benefactor, and who will say he was not a great man when he placed public service before private gain? His attitude in the matter is summed up in the final paragraph of an article on the five famous potato varieties placed on the market between 1882 and 1896 . "It will now appear that for our 16 years of potato work, we have sold five kinds for precisely $\$ 1,000$. We dare say that, had we used our columns for advertising the three kinds now offered for sale, retaining the entire control as long as possible, The Rural New-Yorker might easily have made a snug little fortune. But, tell us friends, were we to crack up the plants that have originated at the "Rural Grounds" while we sold them to you either directly or indirectly, do you think that you would place as much confidence in the thorough impartiality of our plant reports, as you do now?" Ten years ago the writer made a trip through the great potato regions of Wisconsin and Minnesota. During it one of the most successful and best informed growers stated that in the previous decade $80 \%$ of the potatoes of the country were either Mr. Carman's productions or seedlings from them. How much truth there was in this statement it is impossible to say, but discount it as much as one will, can it be said that there is no such thing as altruism?

\section{POTATO CREATIONS.}

The famous potatoes from the Rural Grounds were Rural Blush, Rural NewYorker No. 2, Carman No. 1, Carman No. 3 and Sir Walter Raleigh. They 
were not raised from hand hybridized seed, though this had been the original intention. Sixty-two varieties were grown as prospective parents, but crossing proved impossible; no functional pollen was formed. A few natural seed berries were found, however, and from them aftar years of testing these five kinds proved to be the fittest. Even the records of the maternal parents were lost, but the goal set at the beginning was reached. New potatoes better than the old Early Rose and Peachblow were produced. Considering the amount of time and space at command, it was probably the most successful practical plant brecding experiment ever tried.

In all of the other hybridization work, Mr. Carman made careful castrations of the flowers used as female parents, protected the blossoms from foreign pollen and made the crosses by hand. "Guess work in hybridization or crossing," he says, "is altogether abominable, because it is impossible to know whether anything has been effected or not, while the variations sure to appear in the seedling plants, it will be assumed, are evidences of cross-bred parentage."

One of the most interesting pieces of work brought to a successful conclusion, was a cross between the beardless Armstron; wheat and rye made in 1882 . Several varieties from this cross were finally introduced, but whether they battled successfully with pure wheats or ryes, I have never heard. ${ }^{1}$ The important thing was the variation in a first hybrid generation which was conclusively demonstrated-work which it would be interesting to repeat even now as the constancy or comparative homozygosity of the parents was unknownand the pioneer work of showing the possibility of making crosses between these two generically different cereals. Mr. Carman saw the salient point very clearly as the following quotation shows: "What do they promise? If the hybrids give us a grain less valuable than rye or wheat, nothing will be gained in this case, except the curious fact that a cross between two different genera of grain is possible. This established, however, the way is opened for further hybridization the pregnant results of "wh ch can only be guessed at"

Another int resting specific cross made by $\mathrm{Mr}$. Carman was between the blackberry and the raspberry. It gave nothing of commercial importance, though by repeating it Luther Burbank is said to have produced a valuable berry. Neither Mr. Burbank nor Mr. Carman, however, was the first to make this cross; Mr. Carman, himself, admits obtaining the idea from William Saunders of London, Ontario, who had produced similar hybrids some five years before.

\section{WORK WITH SOLANUMS.}

Mr. Carman's taste evidently was partial to the Solanaceæ. He worked for many years on tomatoes. and suc. ceeded in isolating from his various crosses five types that were worthy of introduction to the trade. They were the Longkeeper, Lemon Blush, Terra Cotta, Autocrat and Democrat. Autocrat and Lemon Blush were known for years as the finest of their kind. He also crossed the common tomato with both the Currant Tomato L. pimpinellifolium and the nearly related genus Physalis. Whether any valuable types were produced from the first cross or not, I have been unable to find out, but it was demonstrated that the first hybrid generation was intermediate in character and that a few of the individuals of the latter generations combined a fairly large size of fruit with the racemic type of inflorescence. The generic cross was not sufficiently fertile to be propagated, and died out after a couple of generations.

Various other crosses of all kinds kept up the interest of Mr. Carman in his work, in which he was efficiently and enthusiastically aided by Mrs. Carman,

IW. Van Fleet, who was associated with Mr. Carman in his breeding work, states that none of the real hybrid types survived continued propagation. Segregation occurred to such an extent that the progeny soon became, to all appearances, either rye or wheat. None of the rye types proved of particular value, but several of the wheat types are still in use. Farmers Bulletin No. 616 of the U. S. Department of Agriculture, "Winter Wheat Varieties for the Eastern States," recommends the soft "Rural New Yorker No. 57," one of Carman's creations. - The Editor. 
although with one exception the rose hybrids were the only ones that were extremely valuable. This was the Carman Gooseberry. Here was a gooseberry that might have revolutionized gooseberry growing since in a limited test it was mildew proof, but unfortunately the seed firm to which it was sold was unable to propagate it.

The roses were perhaps the real attraction of the "Rural Grounds." The Rosa rugosa of Japan was the foundation stock, and upon it were crossed first the Austrian hardy yellow rose known as Harrison's Yellow, then Hybrid Perpetuals and afterwards $\mathrm{Hy}-$ brid Teas. From these crosses hundreds of plants were raised-most of them, of course, worthless, but some of remarkable beauty. From the first cross mentioned came the Agnes Emily Carman, a fine, hardy, longlived, though thorny variety. In color it was like the Jacqueminot, but many times as profuse in blossoming. From other crosses came procumbent roses, hedge roses, tea roses, etc., etc. They did not attain pre-eminence as did the potato varieties but they helped and still help to brighten many a flower garden.
Elbert S. Carman was born on November 30, 1836, in Hempstead, Long Island. He entered Brown University in 1854 , rooming with John Hay. He was obliged to withdraw after two years of work, however, on account of illness. In 1873, he married Agnes E. Brown, by whom he had two children. Immediately after his marriage he moved to River Edge, N. J., where he began to plant and experiment on the place that afterward became so well known as the "Rural Grounds." While here he became so interested in Moore's Rural New-Yorker as a contributor, that he purchased the paper and became its editor in 1876. Through an absolutely open and honest policy, he made this journal a power in the agricultural world. For many years it has stood out against all frauds and impostures to the farmer, even though this went against its monetary interests. Mr. Carman died February 28, 1900, regretted by the many friends he had made in his editorial capacity, who wrote of him like the hero of Leigh Hunt's ever popular poem, "as one who loved his fellow men."

\section{The Chromosome Hypothesis of Heredity}

A working hypothesis of some sort is an essential tool of an advancing branch of experimental science. It behooves us in the study of heredity to use the best hypothesis we have, until it is replaced by a better.

The chief cbjections to the chromosome hypothesis, so far as I can gather them, are:

1. The English pioneer, Bateson, used instead the working hypothesis of somatic segregation.

2. The chromosome hypothesis does not appeal to physiologists and chemists.

3 . The affairs of the chromcsomes may be regarded as a consequence instead of as a cause.

4. Many of the changes of chromosomes and nucleus are still uncertain.

5. The chromosome hypothesis was discredited by Weismann's extensive and untested speculations

On the other hand, there are advantages in the use of the chromosome hypothesis.

1. Batsson's counter hypothesis of somatic segregation has proved barren, and appears to be contradicted by certain facts.

2. Sirasburger's unrivalled experience found the chromosome hypothesis to fit the facts of plant cytology as well as those of inheritance.

3. The chromosome hypothesis fits the breeding facts of the Cambridge school even better than their own hypothesis.

4. It has been used as a fertile working hypothesis by Morgan and his fellow-workers in their unique experiments at Columbia University.

5. It seems to be coming more and more into use in accounts of research in plant breeding. It has, I think, no serious rival. Whether we like it or not, it appears to be here to stay.

It must be remembered that an experimenter does not usually question whether the hypothesis he uses is true or false, but whether it is useful or barren in leading to new experiments or connecting up facts. Working with it will soon show whether it is good or bad.

Joh: Bellixg, Florida Agricultural Experiment Station. 